\title{
Fire Regime Has a Greater Impact Than Selective Timber Harvesting on Vegetation in a Sub-Tropical Australian Eucalypt Forest
}

\author{
Tom Lewis ${ }^{1, *(\mathbb{D})}$, Tracey Menzies ${ }^{2}$ and Anibal Nahuel Pachas ${ }^{1}$ (D) \\ 1 Queensland Department of Agriculture and Fisheries, Agri-Science Queensland, \\ University of the Sunshine Coast, Locked Bag 4, Maroochydore DC, Sunshine Coast, QLD 4558, Australia; \\ nahuel.pachas@daf.qld.gov.au \\ 2 Queensland Department of Agriculture and Fisheries, Agri-Science Queensland, Cnr Cartwright Road and \\ Louisa Street, Gympie, QLD 4570, Australia; tracey.menzies@daf.qld.gov.au \\ * Correspondence: tom.lewis@daf.qld.gov.au
}

\section{check for}

updates

Citation: Lewis, T.; Menzies, T.; Pachas, A.N. Fire Regime Has a Greater Impact Than Selective Timber Harvesting on Vegetation in a Sub-Tropical Australian Eucalypt Forest. Forests 2021, 12, 1478. https://doi.org/10.3390/f12111478

Received: 27 September 2021

Accepted: 24 October 2021

Published: 28 October 2021

Publisher's Note: MDPI stays neutral with regard to jurisdictional claims in published maps and institutional affiliations.

Copyright: (c) 2021 by the authors. Licensee MDPI, Basel, Switzerland. This article is an open access article distributed under the terms and conditions of the Creative Commons Attribution (CC BY) license (https:/ / creativecommons.org/licenses/by/ $4.0 /)$.

\begin{abstract}
We compared selectively harvested and unharvested areas located among treatments of annual burning since 1952, triennial burning since 1973 and an area that had received no prescribed burning, but with a single wildfire in 2006 (one fire in 72 years), in a dry sclerophyll eucalypt forest, south-eastern Queensland, Australia. Historic fire regime, rather than low-intensity, selective timber harvesting (17\% to $37 \%$ live tree basal area removed) had a greater impact on a range of vegetation and soil attributes. Plant taxa composition was influenced more by historic fire regime than recent harvesting; of the $25.5 \%$ of the variation in taxa composition explained, fire treatments alone accounted for $96.4 \%$ of the explained variation and harvesting alone accounted for just $4.8 \%$. Selective harvesting of timber had a predictable influence associated with removal of tree cover and physical impacts associated with extraction of logs. In harvested areas there were increases $(p<0.05)$ in bare-ground cover and in coarse woody debris volumes and decreases in understorey vegetation height, particularly where woody understorey was present. However, overall, the combined effects of timber harvesting and fire regime were relatively minor. These sub-tropical dry eucalypt forests appear to be resilient to the impacts of combined, but low-intensity disturbances.
\end{abstract}

Keywords: fire history; vegetation structure; species composition; disturbance; resilience; partial harvesting

\section{Introduction}

Tropical and sub-tropical forests worldwide are threatened by anthropogenic impacts such as clearing, over-harvesting, a changing climate and inappropriate fire regimes [1-4]. As such, remnant forests need to be carefully managed to preserve their ecological integrity and the impacts of management options such as the use of prescribed fire and timber harvesting need to be understood.

Selective timber harvesting (i.e., partial harvesting) has been a feature of many dry eucalypt forests, including those of sub-tropical Queensland over the last century [5]. Despite the fact that this form of disturbance is widespread across sub-tropical forests, few published studies have reported the impacts of selective harvesting on vegetation assemblages (i.e., structure and composition) in Australia. Most work to date on selective harvesting has taken place in the northern hemisphere e.g., [6-10]. The lack of local information available on the impacts of selective native forest harvesting has likely influenced the negative public perceptions of native forest harvesting in Australia [11,12], especially as some studies do demonstrate a negative impact on certain ecological attributes $[13,14]$. For example, Eyre et al. [13] report impacts of selective timber harvesting on habitat features in dry eucalypt forest in Queensland; they reported a lower density of live trees with hollows and large 
trees in more intensively logged stands. This is of concern as the maintenance of biological diversity is important as part of ecologically sustainable forest management. However, impacts of selective timber harvesting on biodiversity are not always negative [10,15-19]. For example, Penman et al. [15] reported either no change or an increase in native floristic richness after logging in dry eucalypt forest in southern NSW, Australia. Further, as selective harvesting retains substantial biodiversity (i.e., $85-100 \%$ of mammal, bird, invertebrate and plants), carbon and timber stocks, such management should be viewed as distinctly different from deforestation [20].

In addition to timber harvesting, prescribed burning is another common, often co-occurring forest management practice in sclerophyll forests. It is well known that fire regime has an important influence on vegetation structure, composition and richness [21-25]. Long-term frequent fire often results in a more open forest, by reducing the density of the shrub and tree layer vegetation relative to infrequently burnt areas [26-30]. This reduction in woody understorey plant abundance is often countered by an increase in understorey grass layer biomass [27,31,32]. While there are several studies in the subtropical eucalypt forests that document the impacts of frequent fire regimes on vegetation assemblages, structure and diversity e.g., $[25,29,33,34]$, the combined impacts of fire regime and selective harvesting are not well documented. Studies in southern Australia suggest that there are contrasting impacts of logging and fire on different vegetation strata, such as ground layer vs. shrub layer [15] and frequently prescribed burning combined with harvesting may reduce the above-ground carbon stock through declines in large coarse woody debris and large trees [35]. Watson et al. [14] found that the interactive impacts of selective harvesting and frequent fire resulted in greater mortality of trees, with older trees being particularly vulnerable. While fire is considered a natural disturbance in eucalypt forests, ecological theory and empirical evidence suggests that the effect of multiple disturbance agents, when combined, is likely to be greater than that of a single agent e.g., [36-39], suggesting potentially greater impacts and potentially reduced resilience [40] in forests that have been harvested and frequently burnt.

In 2015, a selective harvested operation took place within one of the longest-running fire experiments (the Bauple fire experiment) in the world, which provided an opportunity to investigate the interactive effects of fire regime and timber harvesting. In particular, this study aimed to determine the influence of fire regime, selective timber harvesting and their combined effects on understorey plant composition, richness and structure, ground cover (debris and bare ground), coarse woody debris and topsoil fertility. We focussed on the immediate post-harvest impacts, in the three years following harvesting. We hypothesized that harvesting impacts on these variables would be greater in the most frequently burnt treatment, due to the combined impacts of multiple disturbance agents.

\section{Materials and Methods}

\subsection{Description of the Site and Experiment}

This study was located at Bauple State Forest $\left(25^{\circ} 48^{\prime} \mathrm{S} 152^{\circ} 37^{\prime} \mathrm{E}\right)$ in southeast Queensland, Australia (Figure 1) in an open forest ecosystem dominated by Corymbia citriodora subsp. variegata (F.Muell.) A.R.Bean \& M.W.McDonald, Eucalyptus siderophloia Benth., E. acmenoides Schauer, with E. fibrosa F.Muell. subsp. fibrosa, E. tereticornis Sm., E. moluccana Roxb. and C. intermedia (R.T.Baker) K.D.Hill \& L.A.S.Johnson as co-dominants. Average annual rainfall at the site is $1100 \mathrm{~mm}$ (1950-2019, SILO-Australian climate data from 1989 to yesterday. Available online: https:/ / www.longpaddock.qld.gov.au/silo/, (accessed on 17 December 2019)), with rainfall being higher in summer months. The mean maximum temperature is $27.1^{\circ} \mathrm{C}$, ranging from $31.0^{\circ} \mathrm{C}$ in January to $22.1{ }^{\circ} \mathrm{C}$ in July and mean minimum temperature is $15.2^{\circ} \mathrm{C}$, ranging from $20.7^{\circ} \mathrm{C}$ in January and February to $8.5^{\circ} \mathrm{C}$ in July. The topography consists of undulating hills and rises and the soils are shallow with loamy surface textures (average topsoil $\mathrm{pH}$ of 5.5) and clay loam to clay textures at 30-40 cm depth [41]. 


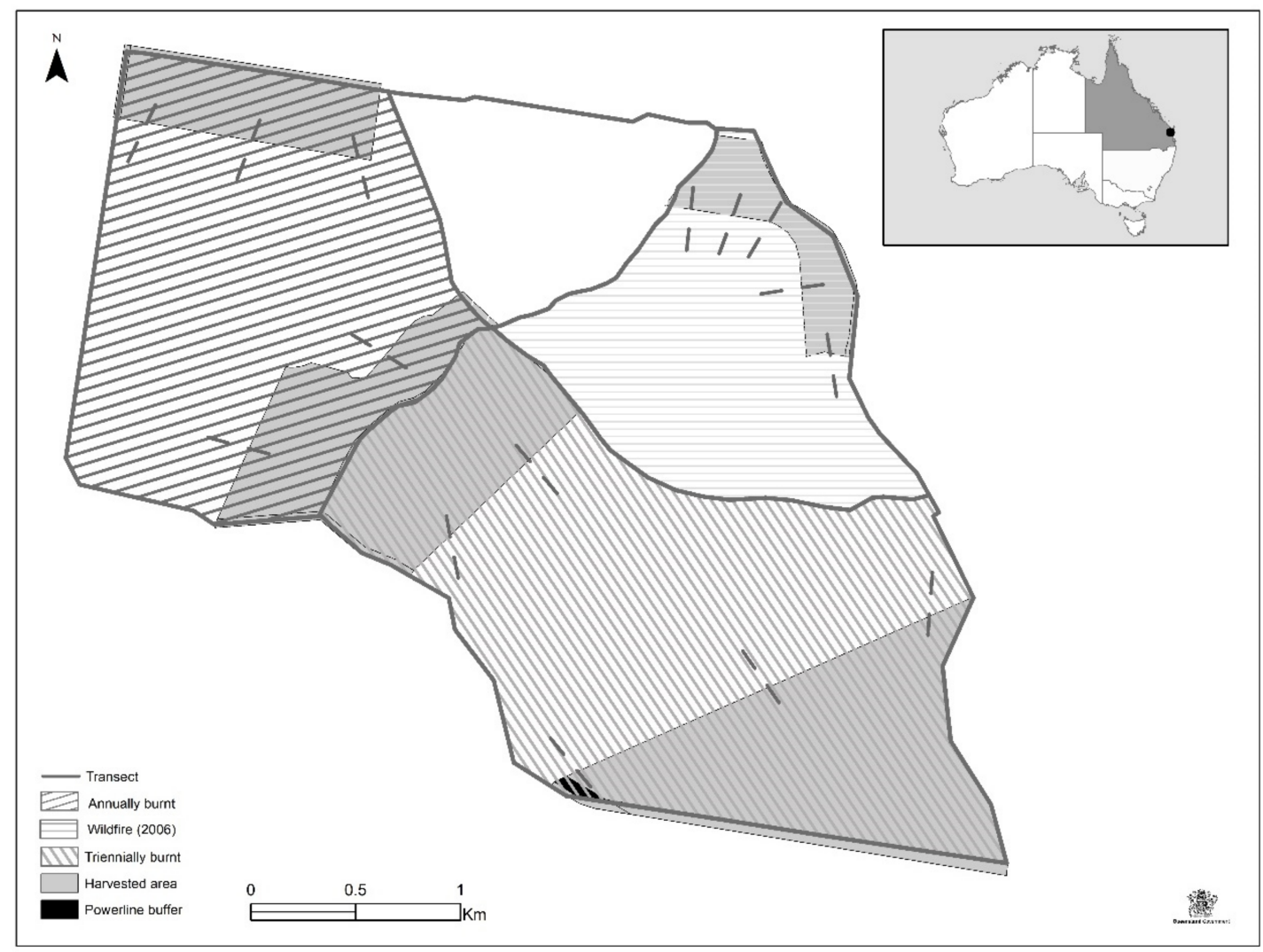

Figure 1. Study site showing locations of monitoring transects in harvested and non-harvested areas within treatments of annual burning, triennial burning and no prescribed burning (wildfire 2006) and location of the site in Australia (inset).

A long-term fire experiment was utilised for this study. This experiment was originally established in 1952 with two treatments: annual burning since 1952 ( 314 ha); and no prescribed burning since 1946 (unburnt treatment, 296 ha). In 1973, a third treatment of triennial burning was added ( $423 \mathrm{ha}$ ). A wildfire burnt through the eastern part of the unburnt treatment (193 ha) in October 2006, effectively splitting the unburnt treatment (Figure 1). The prescribed fire treatments have been continued to present, although not on a strict schedule. Up to the end of 2018, 64 burns (over 67 years) had been attempted in the annually burn treatment and 15 burns (over 46 years) in the triennially burnt treatment. Prescribed burning treatments were conducted in winter and spring (June to October) and are low intensity $\left(<500 \mathrm{~kW} \mathrm{~m}^{-1}\right)$ surface fires, with flame heights generally $<1 \mathrm{~m}$. No fire intensity records were available for the wildfire event in the previously unburnt treatment, but observations made during the fire suggest it was of moderate intensity (500-3000 $\mathrm{kW} \mathrm{m}^{-1}$ ). This wildfire was not a crown fire, it did burn through the mid-storey vegetation in this previously long-unburnt treatment. While there is no true replication of the experimental fire treatments, the treatments have been applied over large areas (Figure 1). In this study, confounding relationships between fire frequency and intensity were unavoidable. That is, the prescribed burning treatments had lower intensity (and severity) fires, while the fire intensity (and presumably severity) was higher in the treatment that was subject to a single wildfire.

Given the long-term nature and scientific value of this experiment, the proposed harvesting was carefully implemented to ensure the value of the experiment was not compromised. To ensure continuity of the long-term data sets from the experiment the existing monitoring plots were protected from the harvesting operation and a $100 \mathrm{~m}$ buffer was placed around each plot. Despite some previous timber harvesting at the fire experiment [25] the effects of harvesting have not yet been quantified at this site. Selective harvesting and silvicultural thinning treatments were last carried out in 1969-1974 across all fire treatments. Thus, this recent harvesting operation presented a good opportunity 
to quantify harvesting impacts. Harvesting adhered to currently accepted Department of Agriculture and Fisheries tree marking guidelines (single tree selection harvesting). Trees were selected and paint-marked for harvesting by experienced operators. This involved marking trees to be removed as sawlogs, power utility poles, girders, fencing and landscaping material, and marking habitat trees for retention. Trees with a DBH (diameter at breast height over bark, $1.3 \mathrm{~m}$ from ground level) of $60 \mathrm{~cm}$ or greater were marked for removal (unless required for habitat or Code of Practice compliance), although this DBH threshold was as low as $40 \mathrm{~cm}$ for certain species (e.g., E. acmenoides), or where the tree was in poor condition (e.g., poor crown health, evidence of decay). Acceptable stems for future products were retained at an approximate spacing of $12 \times 12 \mathrm{~m}$ or $15 \times 15 \mathrm{~m}$, depending on the size of the trees, with a minimum of $6 \mathrm{~m}$ between any two retained trees.

Monitoring transects were established and measured between 16 March and 27 May 2015 and the harvesting took place within and adjacent to these transects (Figure 1) within a period of four months of the first, pre-harvesting assessments. After the pre-harvesting measurements, repeated measurements at the same transects took place in February to June 2016 (approximately six months post-harvesting), April to July 2017 (approximately 20 months post-harvesting) and February to April 2018 (approximately 30 months postharvesting). Thirty transects (15 paired transects) were established; ten transects in each of the three fire treatments, half of which were harvested and half remained unharvested (Figure 1). Each transect was $10 \mathrm{~m}$ wide and $100 \mathrm{~m}$ in length. Transects traversed in the direction perpendicular to the timber harvesting boundary. To ensure the same locations were re-sampled on successive occasions, painted wooden pegs were placed every $50 \mathrm{~m}$ along each transect, and sampling points were marked on the ground with paint. Due to a smaller area available for harvesting in the no prescribed burning treatment, the five transects were separated as much as possible along the logging boundary to reduce spatial dependence among transects within the same treatment (Figure 1). In the prescribed fire treatments transects were position adjacent to existing long-term monitoring plots (separated by $230-650 \mathrm{~m}$ ).

In total, 196 ha was harvested in the triennially burnt treatment, 95 ha was harvested in the annually burnt treatment and 28 ha was harvested in the no prescribed burning treatment. The products and volumes removed varied somewhat between the three treatments (Table 1). This is due to the variation in the amount of area available and the species present in each area. For example, there was more E. acmenoides in the harvested area of the no prescribed burning treatment, and split and round posts were harvested from this species. Due to the selective harvesting regime followed there were still considerable standing volumes of timber in commercial species that had not yet reached their maximum economic potential. On average live tree standing basal area in harvested plots was reduced by $27 \%$ following harvesting ( $25 \%$ in annually burnt plots, $17 \%$ in triennially plots and $37 \%$ in the no prescribed fire treatment). Two transects in the triennially burnt area and one transect in the annually burnt area were not harvested at all. This reflects reality in that some areas within a designated harvest area are not harvested due to environmental restrictions or the size and species mix of the forest. Hence, despite the lack of harvesting at three transects, these transects were retained in our analysis. Overall, there was no significant difference in logging intensity (basal area removed) among the fire treatments $\left(\mathrm{F}_{2,12}=2.3, p>0.05\right)$ due to the high degree of variability among transects.

During the period of this study, prescribed burns were carried out in September 2015 (after logging) in the annually burnt treatment, and September 2016 in the triennially burnt treatment. These burns were considered low intensity and were patchy in nature and mimicked current 'top-disposal' burn practices that are typically carried out following timber harvesting. 
Table 1. Products removed on a per hectare basis (volumes in $\mathrm{m}^{3}$, total length in linear metres ( $\mathrm{lm}$ ) and number of pieces) from triennially burnt, annually burnt and no prescribed fire treatments during harvest operations in 2015.

\begin{tabular}{|c|c|c|c|}
\hline Product Type & Annually Burnt & Triennially Burnt & No Prescribed Fire (Single Wildfire) \\
\hline Compulsory sawlog 1 & $9.7 \mathrm{~m}^{3} / \mathrm{ha}$ & $13.2 \mathrm{~m}^{3} / \mathrm{ha}$ & $19.0 \mathrm{~m}^{3} / \mathrm{ha}$ \\
\hline Optional sawlog 2 & $4.5 \mathrm{~m}^{3} / \mathrm{ha}$ & $4.3 \mathrm{~m}^{3} / \mathrm{ha}$ & $3.2 \mathrm{~m}^{3} / \mathrm{ha}$ \\
\hline Salvage (landscaping) & $3.8 \mathrm{~m}^{3} / \mathrm{ha}$ & $2.2 \mathrm{~m}^{3} / \mathrm{ha}$ & $3.0 \mathrm{~m}^{3} / \mathrm{ha}$ \\
\hline Split posts & nil & nil & 32.4 pieces /ha \\
\hline Round posts & nil & nil & $2.9 \mathrm{~lm} / \mathrm{ha}$ \\
\hline Poles & $27.4 \mathrm{~lm} / \mathrm{ha}$ & $21 \mathrm{~lm} / \mathrm{ha}$ & nil \\
\hline Girders & $2.9 \mathrm{~lm} / \mathrm{ha}$ & $5.6 \mathrm{~lm} / \mathrm{ha}$ & $4.0 \mathrm{~lm} / \mathrm{ha}$ \\
\hline
\end{tabular}

${ }^{1}$ Refers to good quality logs which a purchaser must accept as part of their volume allocation. ${ }^{2}$ Logs where the purchaser has the choice of accept or reject them.

\subsection{Vegetation and Soil Sampling}

Tree data were collected in the full $100 \times 10 \mathrm{~m}$ transects for each year of monitoring. The species and location of all trees $\geq 10 \mathrm{~cm}$ DBH was recorded. Location of each individual was based on the distance along transect, the distance from centre line and which side of the centre line the tree was located. Each tree was allocated a number to allow growth of individuals to be followed over time. The DBH of all trees $\geq 10 \mathrm{~cm}$ was measured. This included dead trees greater than $2 \mathrm{~m}$ in height. The total height $(\mathrm{m})$ of all living trees $\geq 20 \mathrm{~cm}$ DBH was measured using a Vertex ${ }^{\mathrm{TM}}$ (with a hypsometer unit and a transponder) to provide an indication of dominant tree height. Live and dead tree standing basal area of trees $\left(\mathrm{m}^{2} / \mathrm{ha}\right.$ ) and tree density (stems/ha) was calculated for each $100 \times 10 \mathrm{~m}$ transect. Canopy cover was assessed using a spherical densiometer [42] at $20 \mathrm{~m}$ intervals along each transect (i.e., assessed at five evenly spaced points within each $100 \mathrm{~m}$ transect). The mean of four densiometer readings taken at each sample point $\left(90^{\circ}\right.$ to each other) was used to represent that point. As the densiometer was held by the assessor at chest height, this cover estimate sometimes includes small trees (i.e., $<10 \mathrm{~cm} \mathrm{DBH}$ ) that are above this height.

Understorey vegetation was assessed using the point intercept transect method [43]. This involved recording each plant that touched a height stick held vertical at $5 \mathrm{~m}$ intervals along each transect (20 points per transect). The species of plant (or genus, where species could not be determined) was recorded, and the height $(\mathrm{m})$ at which the plant touched the vertical stick (highest point, if the same plant touched the stick in multiple locations) was recorded, up to a height of $7.5 \mathrm{~m}$. Percentage frequency of occurrence for each plant taxon was estimated by dividing the number of points where the taxon touched the stick by the total number of points assessed on the transect, and multiplying by 100 to convert to a percentage. Species richness was determined by summing the number of taxon recorded for each transect.

The percentage ground cover of different plant groups, litter (and debris) cover and bare ground was estimated within $1 \times 1 \mathrm{~m}$ quadrats at $10 \mathrm{~m}$ intervals along each transect (10 points per transect, $10 \mathrm{~m}^{2}$ area). Plant groups were categorized as: perennial grasses (species in the family Poaceae); sedges (monocotyledonous plants not within the Poaceae family); herbs and other herbaceous species (non-grass and sedge species that did not have woody stem); and woody plants with $\mathrm{DBH}<10 \mathrm{~cm}$. Cover of woody plants with $\mathrm{DBH} \geq 10 \mathrm{~cm}$ and grass trees (Xanthorrhoea species) was also recorded, but the cover of these plant groups was very minor and was not included in statistical analysis.

Coarse woody debris (CWD) volume was calculated for each $100 \mathrm{~m}$ transect, by measuring the diameter (at each end of the piece) and length to a minimum diameter of $10 \mathrm{~cm}$, using Smalian's formula (Equation (1)).

$$
\mathrm{V}=\mathrm{L} \times \frac{(\mathrm{Ab}+\mathrm{As})}{2}
$$


where $\mathrm{V}=$ volume $\left(\mathrm{m}^{3}\right), \mathrm{L}=$ length of piece $(\mathrm{m}), \mathrm{Ab}=$ cross-sectional area at large end of the piece, As = cross-sectional area at small end of the piece, both expressed as $\mathrm{m}^{2}$. Each piece of CWD that crossed the transect centre line was measured. This volume is not reported on an area basis but allows a relative comparison between each $100 \mathrm{~m}$ transect. A percentage decay was also attributed to each piece of CWD to account for potential volume loss through decay.

Ground-layer biomass (to $1 \mathrm{~m}$ in height) was assessed at the mid-point of each transect (50 $\mathrm{m}$ point). At each location three sampling positions were randomly selected within a $10 \mathrm{~m}$ radius around each point by collecting all living plant material (separately) that was $<1 \mathrm{~cm}$ diameter and $<1 \mathrm{~m}$ in height. Material was collected from within a $0.5 \times 0.5 \mathrm{~m}$ frame. The collected material was oven dried at $70{ }^{\circ} \mathrm{C}$ to a constant weight and weighed to determine biomass (tonnes per ha).

Topsoil $(0-10 \mathrm{~cm})$ samples were collected at $10 \mathrm{~m}$ intervals along each transect using a push corer (diameter $20 \mathrm{~mm}$ ) and these samples were combined for each transect. The samples were refrigerated then air dried and sieved to a particle size of $<2 \mathrm{~mm}$ for laboratory analysis. The analysis was conducted at the Environmental Analysis Laboratory (Southern Cross University). Soil chemistry tests included phosphorus (P, Bray method for plant available $\mathrm{P}, \mathrm{mg} / \mathrm{kg}$ ), the effective cation exchange capacity (calculated using base saturation of cations, $\mathrm{cmol}+/ \mathrm{Kg}$ ), total carbon $(\mathrm{C})$ and total nitrogen $(\mathrm{N})$ (determined using LECO IR analyser and expressed by percentage) [44].

Temperature near ground level ( 30 to $50 \mathrm{~cm}$ from the ground) was logged using Tinytag ${ }^{\mathrm{TM}}$ sensors on two harvested areas and two unharvested areas in each fire treatment. The sensors in harvested transects were located $50 \mathrm{~m}$ in from the boundary of the harvested area. Data were only available for the post-logging period from September 2016. These sensors recorded temperature every $30 \mathrm{~min}$ to March 2018 allowing calculation of average daily temperatures.

\subsection{Statistical Analysis}

Repeated measures analysis of variance (ANOVA) was carried out in GenStat (18th edition) to compare fire treatment effects (three treatments), harvesting effects and their interactions. Response variables analysed included live and dead tree basal area and density, canopy cover, CWD volume, ground-layer live plant biomass, litter debris biomass, percentage cover of perennial grasses, sedges, herbs and other herbaceous species and woody plants with $\mathrm{DBH}<10 \mathrm{~cm}$, bare ground and litter, transect species richness, average understorey plant height (to $7.5 \mathrm{~m}$ ) per transect, topsoil $\mathrm{P}, \mathrm{N}, \mathrm{C}$ and effective cation exchange capacity. Analysis of covariance was carried out through including pre-harvesting data (2015 assessments) for each variable as a covariate in this analysis, where significant $(p<0.05)$. One-way ANOVA was also used to test for fire treatment effects alone, for the 2015 dataset (pre-harvesting). Daily near-ground temperatures at 9 am were analysed using the REML mixed model procedure where month, fire and harvesting treatments were fitted as fixed effects and transects as random effects.

Least squares regression analysis was used to investigate relationships between harvest intensity (basal area removed from a transect) and response variables in each year. Data transforms were applied (either square root or logarithmic $(x+1))$ in some cases, if necessary, to help meet the assumptions of the analyses. Predicted means (from model output, adjusted for covariates, where significant) and least significant differences (LSD) are reported.

Plant taxa composition was analysed with multivariate analysis carried out using CANOCO version 5 [45]. Partial redundancy analysis (RDA) was used to explain variation in plant density associated with sampling time, fire regime treatments and forest harvesting treatments. RDA, which assumes that plant taxa respond linearly to environmental variables, was used because a preliminary detrended correspondence analysis found that plant responses to environmental predictors were more linear than Gaussian ( $\leq 3$ s.d., [45]). We report taxa composition rather than species composition given that not all taxa were 
reported to species level. A total of 47 plant taxa and 90 samples (30 transects $\times$ three post harvest sampling times) were included in this analysis. Response data transformation and standardization was applied; plant data were transformed by taking logarithms, using the transformation $\ln (10 \times x+1)$, where $x=$ taxa density [45]. Prior to this analysis we tested for spatial autocorrelation [46] among plots using a Mantel test, which compared matrices of: (1) the geographic distance between pairs of transects, and (2) Bray-Curtis similarities of taxa density data averaged across all times, and for the initial (2015) and final (2018) measurements. No significant spatial autocorrelation was detected $(r=0.35,0.37$ and 0.42 , respectively, $p>0.05)$.

\section{Results}

\subsection{Tree Layer}

Across the site in 2015 average canopy height was $27.4 \mathrm{~m}$ and varied from 24.4 to $35.0 \mathrm{~m}$, while average tree cover was $86.0 \%$, varying from $70.6 \%$ to $94.5 \%$. Percentage tree cover was lower in harvested areas after the 2015 harvest $\left(\mathrm{F}_{1,7}=51.15, p<0.001\right)$, but the effects on tree cover varied over time and among fire treatments (time $\times$ fire treatment $\times$ harvesting treatment, $\left.\mathrm{F}_{4,287}=7.36, p<0.001\right)$. Tree cover increased over time in the harvested areas, quite rapidly in the wildfire and triennial burn treatments (Figure 2a), and there were pre-existing differences in tree cover among fire treatments that were accounted for in the analysis $(78.5 \%, 86.9 \%, 92.5 \%$ in the annually, triennially and wildfire treatments, respectively, LSD = 2.6). The density of trees was also significantly lower in harvested areas than in unharvested areas, as expected following a harvest $\left(\mathrm{F}_{1,11}=31.32, p<0.001,267\right.$ and 305 stems $/$ ha, respectively, LSD $=15.4$ ) and there were pre-existing differences in stem density among fire regime treatments $(244,383,267$ stems / ha in the annually, triennially and wildfire treatments, respectively, LSD = 82.3) accounted for in the analysis.

Tree species richness varied from four to 13 trees per transect. Tree species richness was not significantly influenced by either fire treatment or harvesting ( $p>0.05$ in both cases). Live tree basal area increased over time following harvesting $\left(F_{2,48}=105.9, p<0.001\right)$, but remained lower in harvested areas than in unharvested areas over the time period of this study $\left(\mathrm{F}_{1,11}=9.5, p=0.010\right)$. Live tree basal area also differed among fire treatments $\left(\mathrm{F}_{2,11}=8.02, p=0.007\right)$, being higher in the triennial treatment $\left(16.6 \mathrm{~m}^{2} / \mathrm{ha}, \mathrm{LSD}=1.44\right)$ than the wildfire treatment $\left(14.0 \mathrm{~m}^{2} / \mathrm{ha}\right)$, and intermediate in the annual burn treatment $\left(15.1 \mathrm{~m}^{2} / \mathrm{ha}\right)$. There were no significant interactions among fire treatments, harvesting treatment and time (Figure $2 b$ ).

There was a significant fire treatment $\times$ harvest treatment interaction for the basal area of dead trees $\left(\mathrm{F}_{2,11}=7.51, p=0.009\right)$. In the wildfire treatment, the basal area of dead trees was significantly lower in harvested areas than in unharvested areas, but differences were not apparent in the frequently burnt treatments (Figure $2 \mathrm{c}$ ). The covariate was also significant in this case $\left(\mathrm{F}_{1,11}=93.0, p<0.001\right)$, due to pre-existing higher dead tree basal area in the wildfire treatment $\left(\mathrm{F}_{2,12}=8.83, p=0.004 ; 1.01,1.66\right.$ and $3.88 \mathrm{~m}^{2} /$ ha in the annually burnt, triennially burnt and wildfire treatments, respectively, LSD $=1.56$ ). The basal area of dead trees also declined between 2016 and the following two years $\left(\mathrm{F}_{2,48}=7.12, p=0.013\right.$; $1.93,1.78,1.77 \mathrm{~m}^{2} / \mathrm{ha}$, respectively, LSD $=0.11$ ), suggesting some dead trees fell over during this time.

\subsection{Near-Ground Temperature, Vegetation Cover, Structure and Composition}

Average daily near-ground temperature at 9 am varied significantly among months $(p<0.001)$ as expected, with highest average temperatures in January $\left(27.1^{\circ} \mathrm{C}\right)$ and lowest temperatures in July $\left(15.7^{\circ} \mathrm{C}\right)$. There was a significant interaction between fire treatment and harvesting treatment, where unharvested areas of the wildfire treatment registered lower average temperature $\left(22.6^{\circ} \mathrm{C}\right)$ compared to harvested areas in this treatment $\left(23.0^{\circ} \mathrm{C}\right)$ $(p<0.01)$. There was no significant difference in daily temperatures among the other fire and harvesting treatment combinations (means ranging from 22.7 to $23.0^{\circ} \mathrm{C}$ ). 
(a)

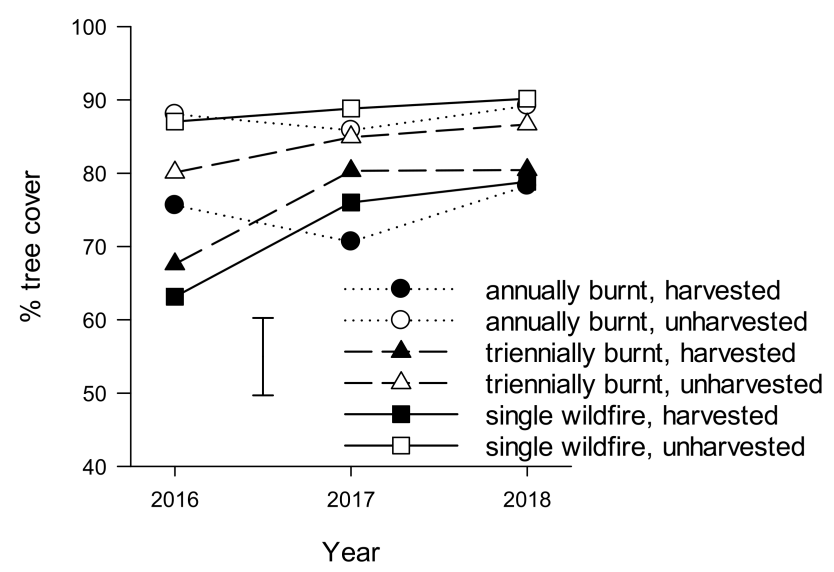

(b)

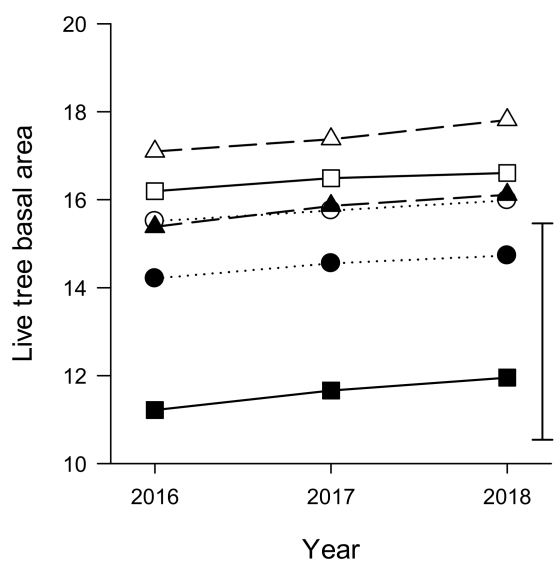

(c)

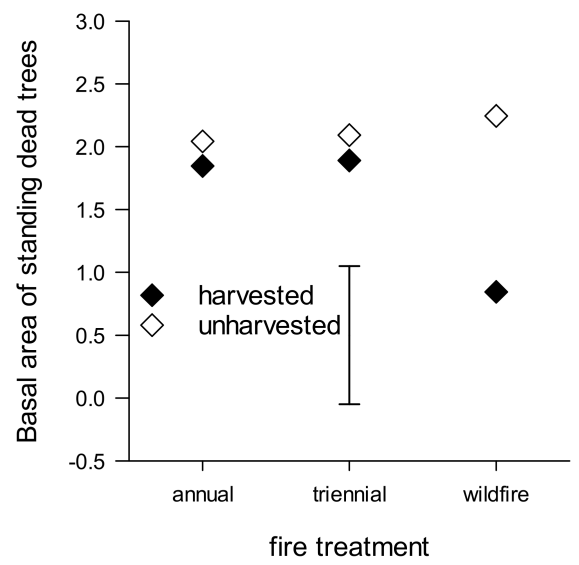

Figure 2. Variation in mean (a) tree cover (\%) and (b) live tree basal area $\left(\mathrm{m}^{2} / \mathrm{ha}\right)$ over time after harvesting (in 2015) in the different harvesting and fire treatments, where there was a significant time $\times$ fire treatment $\times$ harvesting interaction $(p<0.001)$ for tree cover, but no significant interaction $(p>0.05)$ for live tree basal area; and (c) variation in the basal area of standing dead trees in the different harvesting and fire treatments, where the fire treatment $\times$ harvesting interaction was significant $(p=0.009)$. The error bar indicates the LSD in each case.

Ground-layer biomass of living vegetation varied significantly between harvested and unharvested areas $\left(\mathrm{F}_{1,12}=13.65, p=0.003\right)$, but fire treatment effects, variation over 
time and interaction effects were not significant $(p>0.05)$. Across all fire treatments and times, ground-layer biomass of living vegetation was 1.43 tonnes/ha in the harvested treatment and 0.83 tonnes $/$ ha in the unharvested treatment (LSD $=0.35)$. These differences in ground-layer biomass were likely the result of subtle changes in the cover of grasses, sedges and woody plant between harvested and unharvested areas over time. Grass cover varied among fire treatments $\left(\mathrm{F}_{2,275}=9.28, p<0.001\right)$, but the effects of fire treatment on grass cover varied over time and between harvest treatments (time $\times$ fire treatment $\times$ harvesting treatment, $\left.\mathrm{F}_{4,588}=2.64, p=0.045\right)$. Across all times there was also a significant fire treatment $\times$ harvesting treatment interaction $\left(\mathrm{F}_{2,275}=3.22, p=0.042\right)$. Grass cover was generally higher in the annually burnt treatment than the triennial and wildfire treatments, but was higher in unharvested areas of the annually burnt treatment than harvested areas. By contrast, grass cover was higher in harvested areas in both the triennial and wildfire treatments over time (Figure 3a). The covariate was also significant in this case $(p<0.001)$, due to pre-existing differences in grass cover among fire treatments in 2015; grass cover was highest in the annually burnt treatment, intermediate in the triennially burnt treatment and lowest in the wildfire treatment $(51.1,30.4$ and $19.0 \%$, respectively, LSD = 5.8).

The cover of herbs was not significantly influenced by fire treatment, harvesting treatment or the fire treatment by harvesting treatment interaction ( $p>0.05$ in all cases). While herb cover did vary over time $\left(\mathrm{F}_{2,588}=23.65, p<0.001\right.$, Figure $\left.3 \mathrm{~b}\right)$, this is likely due to seasonal conditions at the time of sampling (e.g., recent rainfall). In 2015, herb cover varied significantly among the fire treatments $\left(\mathrm{F}_{2,278}=17.57, p<0.001\right)$, with highest herb cover in the annually burnt treatment, intermediate cover in the triennially burnt treatment and lowest cover in the wildfire treatment $(1.58,0.98$ and $0.05 \%$, respectively, LSD $=0.51)$. The cover of sedges was also not influenced by harvesting treatment alone $(p>0.05)$, although the time $\times$ fire treatment $\times$ harvesting treatment interaction was significant $\left(\mathrm{F}_{4,588}=4.41\right.$, $p=0.002$; Figure 3c). Sedge cover tended to increase more over time in the harvested, wildfire-affected areas than other treatments (Figure 3c). Across all times and harvesting treatments, sedge cover did vary among fire treatments $\left(\mathrm{F}_{2,275}=9.05, p<0.001\right)$ and preexisting differences among treatments were apparent (covariate significant, $\mathrm{F}_{1,275}=4429.7$, $p<0.001$ ). Pre-harvesting, sedge cover was significantly greater in the wildfire treatment than in the frequently burnt treatments $(5.8 \%, 0.9 \%, 0.4 \%$ in the wildfire, triennial and annual burn treatments, respectively, LSD $=1.4$ ).

Timber harvesting had a significant influence on the cover of woody understorey species $\left(\mathrm{F}_{1,17}=10.1, p=0.006\right)$ and this effect varied over time $\left(\mathrm{F}_{2,588}=8.91, p<0.001\right)$. Harvested areas had higher levels of woody understorey cover than unharvested areas and cover tended to increase over time in harvested areas, but did not vary greatly over time in the unharvested areas (Figure 3d). There was also a significant positive relationship between harvest intensity and woody understorey cover in $2017\left(\mathrm{~F}_{1,28}=7.13, p=0.013\right.$, adjusted- $\left.R^{2}=0.17\right)$ and $2018\left(\mathrm{~F}_{1,28}=5.43, p=0.027\right)$, adjusted- $\left.\mathrm{R}^{2}=0.13\right)$, but not in 2016 $(p>0.05)$. There were pre-existing differences among fire treatments accounted for in the ANOVA (covariate significant, $\mathrm{F}_{1,17}=19.86, p<0.001$ ). In 2015, woody understorey cover varied significantly due to fire regime treatment $\left(\mathrm{F}_{2,278}=27.4, p<0.001\right)$, with highest cover in the wildfire treatment, intermediate cover in the triennial treatment and lowest cover in the annually burnt treatment $(13.1,9.4,2.1 \%$, respectively, LSD $=3.0)$. The fire treatment by harvesting treatment interaction had no significant influence on woody understorey cover $(p>0.05)$ in this study. 

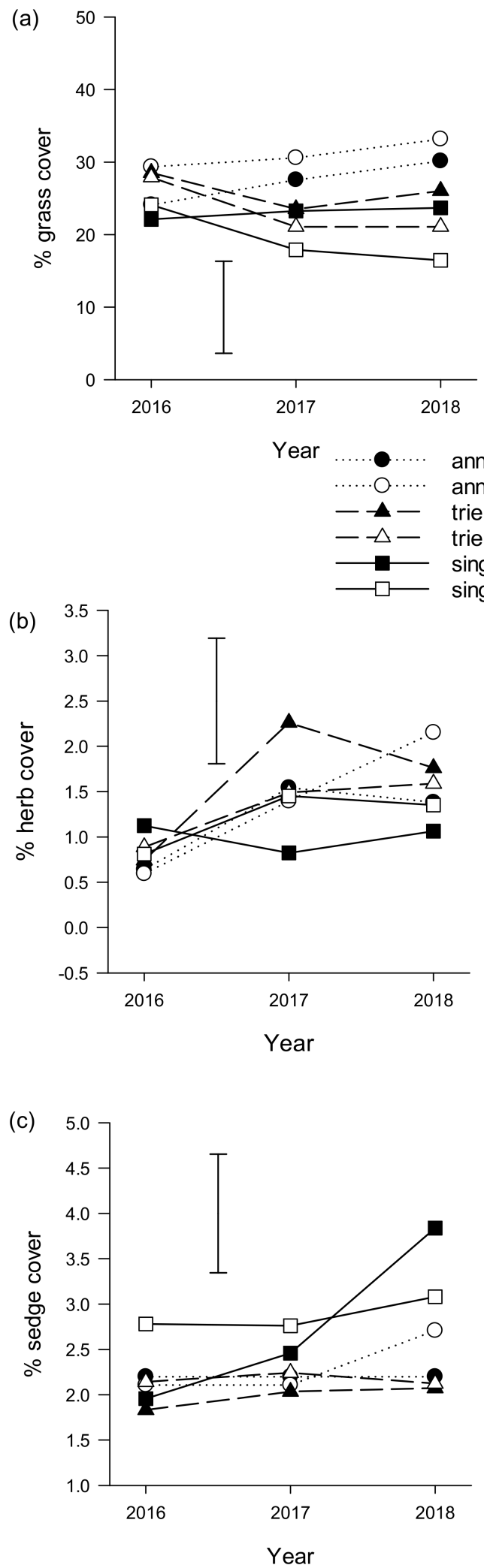

(d)

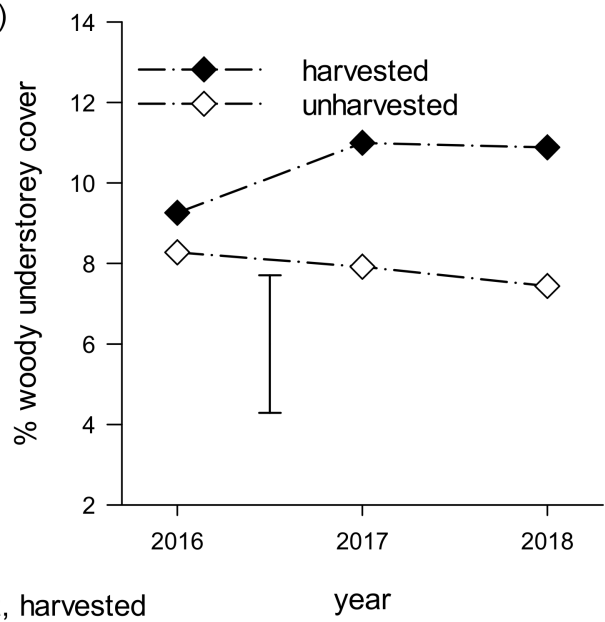

annually burnt, harvested annually burnt, unharvested triennially burnt, harvested triennially burnt, unharvested single wildfire, harvested single wildfire, unharvested

(e)

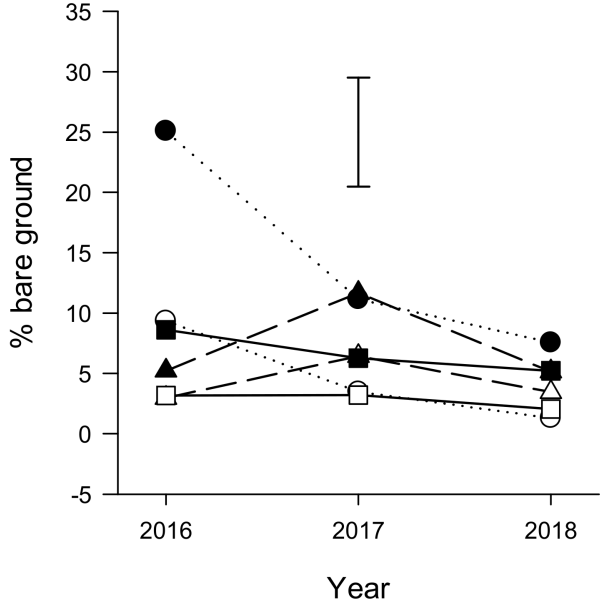

(f)

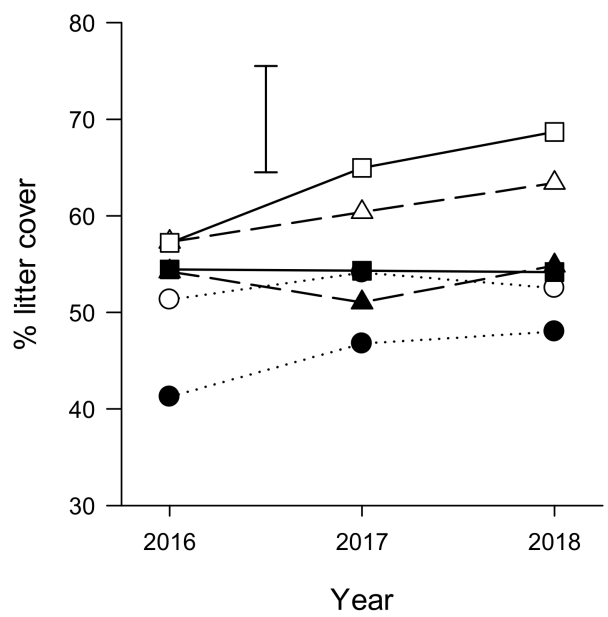

Figure 3. Variation in mean percentage cover of different attributes over time in harvested and unharvested transects. There were significant time $\times$ fire treatment $\times$ harvesting interactions for: (a) perennial grasses, (b) herbs, (c) sedges, (e) bare ground and (f) leaf litter; and a significant time $\times$ harvesting interaction for woody plant understorey cover (d). Prescribed burns took place in 2015 in the annually burnt treatment and 2016 in the triennially burnt treatment. The error bar indicates the LSD. 
Plant species richness was not significantly influenced by fire treatment or harvesting and did not vary significantly over time ( $p>0.05$ in all cases). In addition, no interaction terms were significant for this variable (Appendix A). On average 12.9 plant species were recorded on a given $100 \mathrm{~m}$ transect. However, there was a significant positive relationship between species richness and harvest intensity in $2018\left(\mathrm{~F}_{1,28}=10.8, p=0.003\right.$, adjusted- $\left.\mathrm{R}^{2}=0.25\right)$ that was not seen in other years $(p>0.05)$ suggesting some lag in species richness response after harvesting. Fire treatment and harvesting both had a significant influence on plant taxa composition (pseudo-F $=15.7$ and 2.4, respectively, $p=0.002$ in both cases). Year of sampling did not influence plant composition (pseudo- $\mathrm{F}=0.8, p>0.05$ ) in this relatively short-term study. The full model explained $25.5 \%$ of the variation in taxa composition. Variance partitioning showed that fire treatments accounted for $96.4 \%$ of the explained variation and harvesting accounted for just $4.8 \%$ of the explained variation, with $1.2 \%$ of the variation explained by the combined effects of fire treatment and harvesting. There were a group of taxa that were more abundant in the single wildfire treatment, including Acacia leiocalyx, Gahnia aspera, Cyclophyllum coprosmoides, Lomandra sp. and Entolasia stricta (Figure 4). Grass species and herbs were more abundant in the frequently burnt treatments (Figure 4), with species such as Themeda triandra, Flemingia parviflora, Glycine clandestina and Eremochloa bimaculata more strongly associated with annually burnt areas. Only two non-native species (Lantana camara and Passiflora suberosa) were recorded during this study and both were weakly associated with the wildfire treatment (Figure 4).

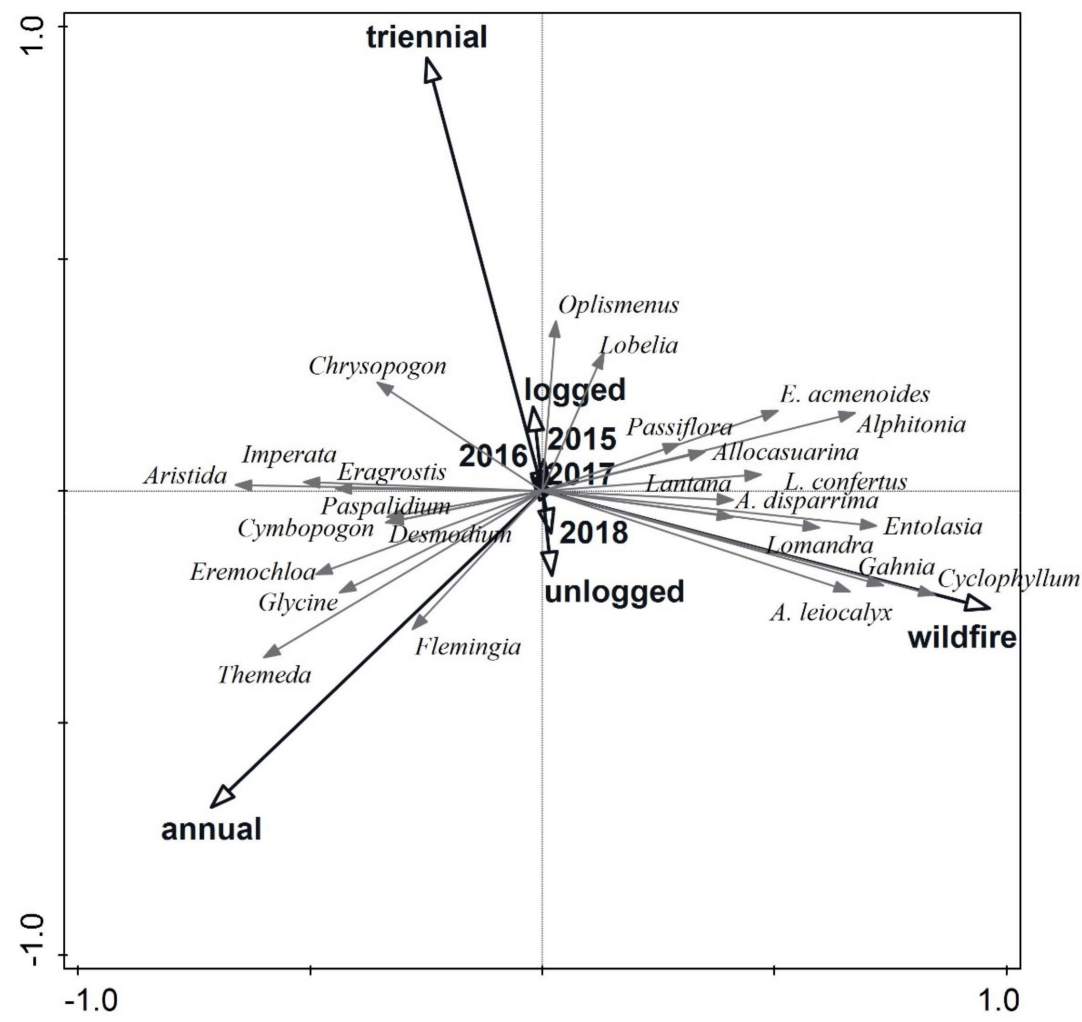

Figure 4. Redundancy analysis output, showing the important influence of fire treatments on taxa composition, with timber harvesting and sampling time having a much smaller influence. The 25 taxa that were best explained by the model are included. These were: Flemingia, F. parviflora; Themeda, T. triandra; Glycine, Glycine clandestina; Eremochloa, E. bimaculata; Desmodium, D. rhytidophyllum; Cymbopogon, C. refractus; Paspalidium, Paspalidium sp.; Arisitda, Aristida sp.; Eragrostis, Eragrostis sp.; Imperata, I. cylindrica; Chrysopogon, C. fallax; Oplismenus, O. aemulus; E. acmenoides, Eucalyptus acmenoides; Alphitonia, A. excelsa; Allocasuarina, A. littoralis; Lantana, L. camara; A. disparrima, Acacia disparrima; Entolasia, E. stricta; Lomandra, Lomandra sp.; Gahnia, G. aspera; Cyclophyllum, C. coprosmoides; A. leiocalyx, Acacia leiocalyx. 
Average understorey vegetation height differed significantly between harvested and unharvested treatments $\left(\mathrm{F}_{1,11}=12.66, p=0.004\right)$, among fire treatments $\left(\mathrm{F}_{2,11}=5.13\right.$, $p=0.027)$ and the fire treatment $\times$ harvesting treatment interaction was significant $\left(\mathrm{F}_{2,11}=4.89\right.$, $p=0.030)$. Understorey vegetation height was lower in harvested areas than unharvested areas of the single wildfire treatment, but differences in understorey height did not vary greatly between harvested and unharvested areas of the two frequently burnt treatments, which tended to have lower understorey vegetation heights (Figure 5). There were also pre-existing differences among fire treatments $\left(\mathrm{F}_{1,11}=7.17, p=0.021\right)$ that were accounted for in this analysis. Pre-harvesting, there was a significant difference in understorey height among treatments $\left(\mathrm{F}_{2,12}=34.4, p<0.001\right)$, with greater understorey heights in the wildfire treatment $(2.9 \mathrm{~m})$ compared to either of the frequently burnt treatments $(0.8$ and $1.1 \mathrm{~m}$ in the annually and triennially burnt treatments, respectively, LSD $=0.58$ ).

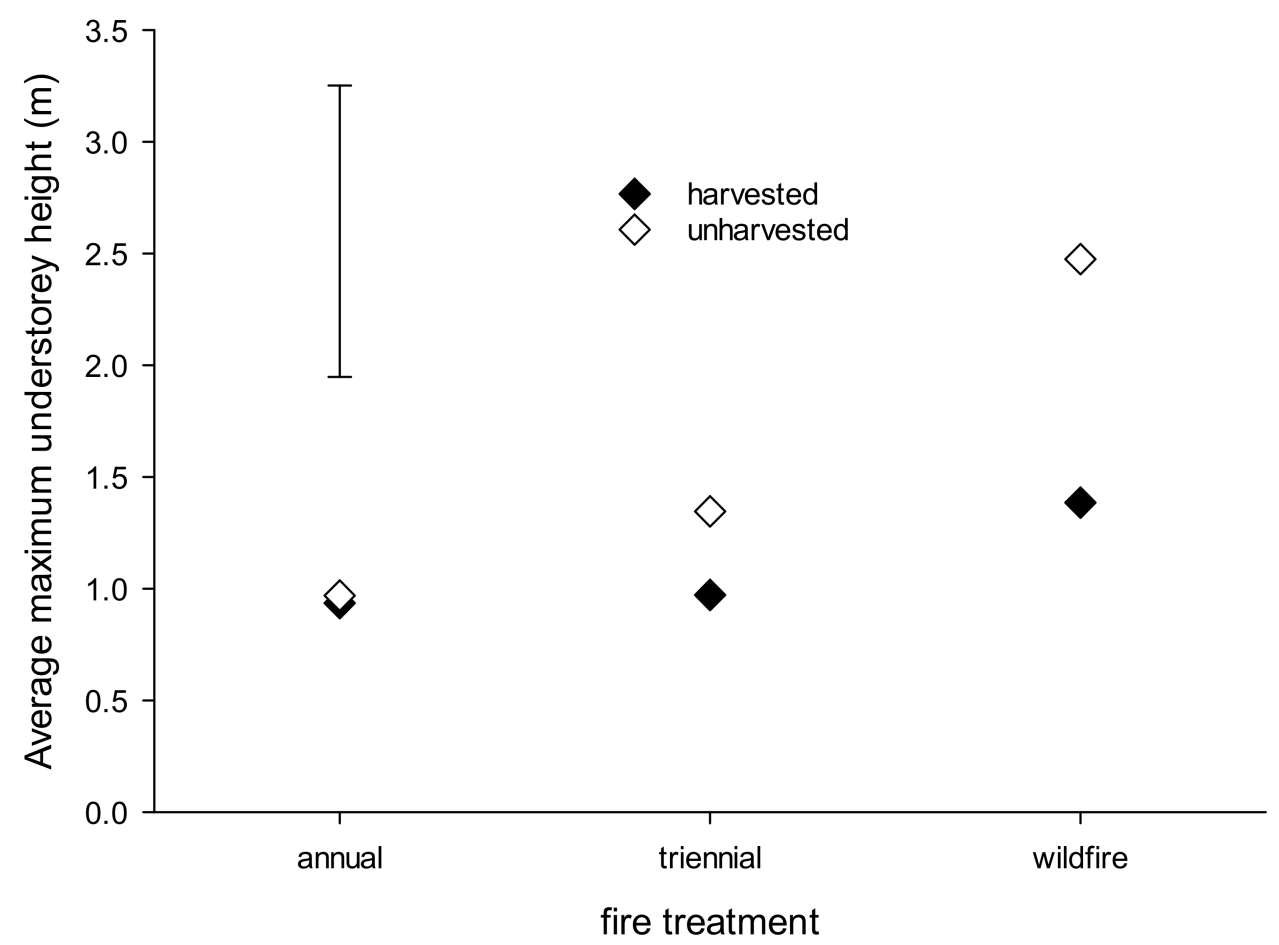

Figure 5. Mean maximum understorey vegetation height for harvested and unharvested transects in each of the three fire treatments. There was a significant fire treatment $\times$ harvesting treatment interaction $(p<0.05)$. The error bar indicates the LSD based on fire treatment $\times$ harvesting treatment interaction.

\subsection{Bare Ground and Debris}

The influence of fire treatment on bare ground cover varied between the harvesting treatments $\left(\mathrm{F}_{2,275}=5.49, p=0.005\right)$ and the three-way interaction with time was also significant $\left(\mathrm{F}_{4,588}=7.45, p<0.001\right.$; Figure $\left.3 \mathrm{e}\right)$. Fire treatment also had a pre-existing influence on bare ground cover (covariate significant, $\mathrm{F}_{1,275}=49.34, p<0.001$ ) that was accounted for in the analysis, with bare ground cover being greater in both frequently burnt treatments, relative to the wildfire treatment $(5.6,4.7$ and $2.1 \%$ in the annually, triennially and wildfire treatments, respectively, LSD = 2.0). The three-way interaction appeared to be partly the result of time since the last fire effects; the harvested, annually burnt treatment had high bare ground cover after the combined effects of harvesting and prescribed fire in 2016, and the harvested, triennially burnt areas had higher bare ground in 2017, following the September 2016 burn in these areas (Figure 3e). Over all times, the harvested, annually burnt areas had higher bare ground cover than the harvested areas in the other fire treatments $(14.6 \%$, compare to 7.3 and $6.7 \%$ in the triennial and wildfire treatments, respectively, LSD $=3.9 \%$ ). 
Both fire treatment $\left(\mathrm{F}_{2,275}=18.51, p<0.001\right)$ and harvesting $\left(\mathrm{F}_{1,17}=22.88, p<0.001\right)$ had a significant influence on litter cover, but the fire treatment $x$ harvesting treatment interaction was not significant $\left(\mathrm{F}_{2,275}=0.29, p>0.05\right)$. There was a significant time $\times$ fire treatment $\times$ harvesting treatment interaction $\left(\mathrm{F}_{4,588}=8.99, p<0.001\right)$. Litter cover increased over time in all cases, but the increases were less pronounced in the harvested areas (across all fire treatments) relative to unharvested areas (Figure 3f). There were pre-existing differences in litter cover among the fire treatments (covariate significant, $\left.\mathrm{F}_{1,275}=326.53, p<0.001\right)$ that were accounted for in the analysis. In 2015, litter cover was highest in the wildfire treatment, intermediate in the triennially burnt treatment and lowest in the annually burnt treatment $(59.0,52.6,39.3 \%$, respectively, LSD $=5.9)$.

Coarse woody debris volume was significantly influenced by timber harvesting $\left(\mathrm{F}_{1,12}=12.48, p=0.004\right)$, but was not influenced by fire treatment, sampling time or any interaction terms $(p>0.05)$. Across all fire treatments and times, coarse woody debris volumes were higher in harvested areas than unharvested areas (log transformed means of 0.42 and $0.17 \mathrm{~m}^{3}$ per transect, respectively, LSD $=0.15$ ). There was a significant positive relationship between harvesting intensity and coarse woody debris volume after harvesting (e.g., in 2016, $\mathrm{F}_{1,28}=10.58, p=0.003$, adjusted- $R^{2}=0.25$ ).

\subsection{Topsoil}

Topsoil \%C varied significantly among fire treatments $\left(\mathrm{F}_{2,11}=6.62, p=0.013\right)$, with higher $\% \mathrm{C}$ in the triennial and wildfire treatments, relative to the annually burnt treatment $(2.47,2.38$ and $2.11 \%$, respectively, $\mathrm{LSD}=0.22)$. Fire treatment also had a pre-existing influence on $\% \mathrm{C}$ (covariate significant, $\mathrm{F}_{1,11}=14.78, p=0.003$ ) that was accounted for in the analysis. The effects of timber harvesting, sampling time and the interaction terms were all non-significant for this variable ( $p>0.05$, Appendix A). Topsoil $\% \mathrm{~N}$ varied significantly among fire treatments $\left(\mathrm{F}_{2,11}=4.88, p=0.030\right)$, harvest treatment $\left(\mathrm{F}_{1,11}=5.16, p=0.044\right)$ and over time $\left(\mathrm{F}_{2,48}=5.24, p=0.022\right)$, but no interactions were significant $(p>0.05$, Appendix A). Fire treatment also had a pre-existing influence on $\% \mathrm{~N}$ (covariate significant, $\mathrm{F}_{1,11}=56.09$, $p<0.001)$. The triennial burn treatment had higher $\% \mathrm{~N}$ than the annually burnt treatment $(0.113 \%, 0.100 \%$, respectively, LSD $=0.009)$, while the wildfire treatment had intermediate $\% \mathrm{~N}(0.106 \%)$. The harvested treatment had a lower $\% \mathrm{~N}$ than the unharvested treatment $(0.102 \%$ and $0.111 \%$, respectively, LSD $=0.009)$. Across all treatments $\% \mathrm{~N}$ declined somewhat over time $(0.113 \%, 0.105 \%$ and $0.101 \%$ in 2016, 2017 and 2018, respectively, $\mathrm{LSD}=0.008)$. There was an initial significant negative relationship between topsoil \% $\mathrm{N}$ and harvest intensity in $2016\left(\mathrm{~F}_{1,28}=9.82, p=0.004\right.$, adjusted- $\left.R^{2}=0.23\right)$, that was no longer significant in 2017 or 2018 ( $p>0.05)$.

Effective cation exchange capacity did not vary significantly in response to treatments and no interaction terms were significant $(p>0.05)$. Bray $\mathrm{P}$ varied among fire treatments $\left(\mathrm{F}_{2,11}=4.94, p=0.027\right)$ and over time $\left(\mathrm{F}_{2,48}=31.95, p<0.001\right.$, Appendix A $)$. The annually burnt treatment had significantly higher Bray $\mathrm{P}$ than the wildfire treatment and the triennially burnt treatment had an intermediate value (log transformed means of 0.592, 0.502 and 0.548 , respectively, $\mathrm{LSD}=0.062$ ). Across all treatments, Bray P declined somewhat over time (log transformed means of 0.627, 0.578 and 0.437, in 2016, 2017 and 2018, respectively, $\mathrm{LSD}=0.053$ ).

\section{Discussion}

The hypothesis that selective timber harvesting in frequently burnt areas would have a greater impact on a range of ecological variables than in less frequently burnt areas was not well supported. Only bare ground cover was statistically higher in harvested areas subject to annual burning. Although, this effect was strongly influenced by time since last fire, with greater levels of bare ground (and lower litter cover) initially after burning and harvesting, but a reduction in bare ground cover in these areas over time (Figure 3e). Higher levels of bare ground in harvested and burnt areas might be expected due to the burning of fallen tree canopies and a reduction in litter cover (associated with 
likely elevated fire intensity in these patches) and the influence of harvest machinery used for snigging logs from the forest. Prescribed fire after timber harvesting (referred to locally as top-disposal burning) is a common practice in dry eucalypt forests. Fortunately, existing timber harvesting regulations in the project study area (i.e., [47], Code of Practice), require soil conservation measures (e.g., drainage in roads and skid tracks, slope restrictions for harvesting, buffer zones around streams) so it is unlikely that the short-term increases in bare soil resulted in loss of topsoil from the site. Nevertheless, studies on topsoil loss associated with selective timber harvesting are rare in Australia, and it is conceivable that some removal of sediment occurs during heavy rainfall events soon after harvesting [48].

For some variables the combination of infrequent wildfire (approximately 10 years prior) and harvesting had a greater impact than frequent fire and harvesting. For example, in the infrequent wildfire treatment, the basal area of dead trees was significantly lower in harvested areas than in unharvested areas (Figure 2c), suggesting harvesting caused some standing dead trees to fall over. Standing dead trees were more common in the wildfire treatment initially (in 2015), presumably due to mortality of some trees following the wildfire. Standing dead trees provide important habitat for certain native fauna [49-51] and hence this might be an undesired consequence of harvesting in wildfire affected areas. However, it is noted that the standing dead trees were still present on the forest floor (as downed coarse woody debris), where they also provide some habitat value [52-54]. Understorey vegetation height was also lower in harvested areas than unharvested areas of the single wildfire treatment, but differences in understorey height did not vary greatly among harvested and unharvested areas of the two frequently burnt treatments. This was largely due to the existing differences in understorey height among the fire regimes, with greater understorey heights associated with woody plant species more abundant in the wildfire treatment (i.e., C. coprosmoides and A. leiocalyx). The process of harvesting (falling trees and machinery) smashed and squashed some of these woody understorey plants, reducing their height. However, there was an increase in woody plant cover over time in the harvested areas following harvesting (Figure 3d).

Combined effects of fire and selective cutting on vegetation were also minor in Sudanese savanna woodlands [55] and for eucalypt forests in southern Australia [15]. However, stronger interactive effects of fire and timber harvesting have been reported elsewhere e.g., $[14,56,57]$. Barefoot et al. [56] reported that overstorey thinning coupled with prescribed fire resulted in increases in ground flora richness, diversity and cover in mixed Pinus-hardwood stands in Alabama, USA. While positive responses can be evident for ground-layer flora, there may be negative consequences for other ecosystem attributes. For example, in southern Australia, Watson et al. [14] reported that harvesting damage when combined with frequent fire increased mortality rates of retained trees. They suggested a reduced intensity of selective harvesting to address some of the issues associated with loss of large trees which are important for habitat. In their study in temperate forests in Australia selective harvesting removed $60-70 \%$ of the stand basal area. This is much greater than in the current study, where selective harvesting only removed $17 \%$ to $37 \%$ of the stand basal area in the different fire treatments. The relatively low intensity and localised nature of harvesting (i.e., where most areas remain undisturbed, but localised areas, such as snig tracks, may be heavily disturbed) applied in the current study undoubtedly encouraged plant community resilience. Further, multi-aged and multi-species forests often show greater levels of resistance and resilience to disturbance agents [58,59]. However, further work is needed to determine the impacts of selective harvesting at higher intensities, and we acknowledge that our results are not widely applicable across all selective harvesting regimes. Due to the inherent variability in these natural forests, and the relatively low replication in our study, it is possible that some fire regime and harvesting interactions were undetected.

While we focussed on the immediate post-harvest impacts in the three years following harvesting, it is likely that these impacts will be nullified over time. For several of the variables investigated differences between harvested and unharvested areas decreased 
with time, even within the short timeframe of this study. Attributes such as tree cover increased over time in harvested areas (Figure 2a) suggesting they will reach level similar to those of the unharvested areas within a decade, whilst bare ground cover in annually burnt and harvested areas decreased rapidly over the course of this study (Figure 3e). Most of the vegetation responses to harvesting were predictable, such as the reductions in tree cover, tree density, tree basal area and understorey vegetation height in recently harvested areas, but increased ground layer biomass and woody understorey cover in response to removal of some canopy cover and higher levels of coarse woody debris associated with tree heads that remain after harvesting. Similar responses to selective harvesting are common in the literature e.g., $[8,10,60,61]$.

The effects of long-term fire treatments on understorey vegetation assemblages and topsoil were generally greater than the short-term effects associated with timber harvesting. In fact, fire regime had a significant influence on most of the variables measured. In most cases the largest differences were between the annually burnt treatment and the area affected by infrequent wildfire. Tree canopy cover, dead tree basal area, sedge cover, woody understorey vegetation cover, understorey vegetation height, litter cover and topsoil $\% \mathrm{C}$ were higher in the wildfire affected area, and there was a distinct group of woody species and sedges associated with this area. On the contrary, grass cover, herb cover, bare ground cover and available $\mathrm{P}$ were higher in the annually burnt area than the wildfire affected area. Triennially burnt areas tended to have intermediate values (e.g., litter cover, woody understorey cover, grass cover, tree cover), or were more similar to annually burnt areas (e.g., bare ground cover, understorey height, sedge, herb cover, dead tree basal area). There were a group of grasses and herbs that were more abundant across both frequently burnt treatments (Figure 4). The diversity and cover of such species is known to be higher in forests with lower levels of canopy cover and subsequent higher levels of solar radiation $[27,31]$. Only tree density and topsoil $\% \mathrm{~N}$ and $\% \mathrm{C}$ had higher values in triennially burnt areas than annually burnt areas.

There was no evidence of a change in plant taxa diversity in response to fire regime or recent harvesting, and most of the differences in plant composition were associated with fire regime rather than harvesting. A number of other studies have also demonstrated resistance or resilience of plant communities associated with partial harvesting $[9,10,15,62,63]$. Our findings suggest that silvicultural management regimes applied here have a relatively benign influence on vegetation communities, perhaps due to the relatively low intensity of harvesting and soil disturbance [7]. Hence infrequent and low intensity selective timber harvesting is unlikely to have a long-term negative and irreversible impact on most vegetation ecosystem components in similar dry eucalypt forests. Currently, there is relatively little machine activity in harvested areas in similar forest types in the region (i.e., often only snigging machinery within the forest), but as mechanical harvesting is becoming more frequently used in the region, further studies are needed to document the impacts of this machinery, particularly on soil disturbance. The profound differences in plant composition associated with fire frequency regime highlight the important influence of fire management in these forests. Our findings show a clear preference for certain grasses (Poaceae) and herbs to frequently burnt areas, which is supported by literature elsewhere $[27,29,31,32]$. These findings suggest that a mix of fire regimes (i.e., pyrodiversity), including very frequent regimes, is likely to encourage plant diversity across the landscape, a finding that is generally supported by ecological literature on vegetation [64-67].

Fire regime also had a greater influence on the soil attributes measured than timber harvesting. Topsoil $\% \mathrm{C}, \% \mathrm{~N}$ and available $\mathrm{P}$ were all influenced by fire history treatments, but only $\% \mathrm{~N}$ was influenced by harvesting (with a small negative impact of harvesting). There were no interactions for these soil variables (Appendix A) to suggest that the combined influence of fire regime and harvesting had a greater impact than either alone. The influence of fire regime on soil fertility has been thoroughly studied, and the results reported here generally align with those reported globally [68] and at this site $[41,69]$. For example, the lower $\% \mathrm{C}$ and $\% \mathrm{~N}$ in the annually burnt topsoil is in accordance with impacts 
of biennial burning in wet eucalypt forest [70-72]. Higher levels of plant available $\mathrm{P}$ in the most frequently burnt ecosystem support the findings of others who show that organic $P$ concentrations are often enhanced or maintained by occurrence of fire e.g., [41,73].

\section{Conclusions}

This study was conducted to investigate the influence of fire regime, selective timber harvesting and their combined effects on vegetation and soil attributes. Our results suggest that historic fire regime, rather than low-intensity, selective timber harvesting has a greater impact on community composition and a range of vegetation and soil attributes. Annually burnt areas were clearly distinct from infrequently burnt areas (one wildfire in 72 years) in terms of plant taxa composition. Tree canopy cover, dead tree basal area, sedge cover, woody understorey vegetation cover, understorey vegetation height, litter cover and topsoil $\% \mathrm{C}$ were lower in the annually burnt areas, while grass cover, herb cover, bare ground cover and available $\mathrm{P}$ were higher in the annually burnt areas. Triennially burnt areas tended to have intermediate values or were more similar to annually burnt areas. These sub-tropical dry eucalypt forests appear to be resilient to the combined impacts of multiple, low intensity disturbances as there was little evidence to suggest that frequently burnt areas were impacted by selective harvesting to a greater extent than infrequently burnt areas. This is at least partly because fire is a natural disturbance agent in these landscapes and the impacts of selective timber harvesting tend to be localised.

Author Contributions: Conceptualization, T.L.; methodology, T.L. and T.M.; formal analysis, T.L. and A.N.P.; data curation, T.L.; writing—original draft preparation, T.L.; writing—review and editing, T.L., T.M. and A.N.P.; visualization, T.L.; project administration, T.L. All authors have read and agreed to the published version of the manuscript.

Funding: This research did not receive any specific grant from funding agencies in the public, commercial, or not-for-profit sectors.

Data Availability Statement: The data presented in this study are available on request from the corresponding author. The data are stored on http://lavml040.dnr.qld.gov.au/data/qfri, but this database is not publicly available due to Intellectual Property restrictions.

Acknowledgments: This work is based on a long-term fire experiment maintained by Department of Agriculture and Fisheries and the Queensland Parks and Wildlife Service and all the contributors to this experiment over time are acknowledged. We are grateful to the support received from the Department of Agriculture and Fisheries staff (e.g., Daniel Hall) who assisted with the selective harvesting and provided information of products extracted. Tony Burridge, John Huth, Anton Zbonak, Valerie Debuse, Scott Swift, Leanne Bridges and Bruce Hogg assisted with the field measurements and Valerie Debuse assisted with the experimental design and Bruce Hogg assisted with data curation. The Queensland Rural Fire Service are thanked for operational support provided to continue the experimental burning. Peter Leeson, Paul Harris and Darrell Bell have been instrumental in ensuring continuation of the fire treatments at this site.

Conflicts of Interest: The authors declare no conflict of interest. 


\section{Appendix A}

Table A1. Summary of $p$-value significance based on repeated measures analysis of variance (ANOVA) or a REML mixed models for response variables measured at the Bauple long-term fire experiment from 2015 to 2018. NS, not significant $(p>0.05)$. Fire treatments were annual and triennial prescribed fire and no prescribed fire (wildfire only), timber harvesting treatments were harvested or not harvested in 2015.

\begin{tabular}{|c|c|c|c|c|c|c|c|}
\hline Response Variable & Time & $\begin{array}{c}\text { Fire } \\
\text { Treatment }\end{array}$ & Harvesting & $\begin{array}{c}\text { Fire } \times \\
\text { Harvesting }\end{array}$ & Time $\times$ Fire & $\begin{array}{c}\text { Time } \times \\
\text { Harvesting }\end{array}$ & $\begin{array}{c}\text { Time } \times \text { Fire } \times \\
\text { Harvesting }\end{array}$ \\
\hline Tree canopy cover (\%) & $<0.001$ & NS & $<0.001$ & NS & $<0.001$ & $<0.001$ & $<0.001$ \\
\hline Tree density (stems/ha) & $<0.001$ & NS & $<0.001$ & NS & NS & NS & NS \\
\hline $\begin{array}{l}\text { Tree richness (number } \\
\text { per transect) }\end{array}$ & NS & NS & NS & NS & NS & NS & NS \\
\hline Live tree basal area $\left(\mathrm{m}^{2} / \mathrm{ha}\right)$ & $<0.001$ & 0.007 & 0.010 & NS & NS & NS & NS \\
\hline Dead tree basal area $\left(\mathrm{m}^{2} / \mathrm{ha}\right)$ & 0.013 & NS & 0.001 & 0.009 & NS & NS & NS \\
\hline Near ground temperature $\left({ }^{\circ} \mathrm{C}\right)$ & $<0.001$ & NS & NS & $<0.001$ & NS & NS & NS \\
\hline Ground-layer biomass (t/ha) & NS & NS & 0.003 & NS & NS & NS & NS \\
\hline Grass cover $(\%)$ & $<0.001$ & $<0.001$ & NS & 0.042 & $<0.001$ & $<0.001$ & 0.045 \\
\hline Herb cover $(\%)$ & $<0.001$ & NS & NS & NS & 0.006 & NS & 0.017 \\
\hline Sedge cover $(\%)$ & $<0.001$ & $<0.001$ & NS & NS & 0.002 & NS & 0.002 \\
\hline Woody understorey cover (\%) & NS & NS & 0.006 & NS & $<0.001$ & $<0.001$ & NS \\
\hline $\begin{array}{l}\text { Understorey plant species richness } \\
\text { (number per transect) }\end{array}$ & NS & NS & NS & NS & NS & NS & NS \\
\hline Understorey vegetation height (m) & NS & 0.027 & 0.004 & 0.030 & NS & NS & NS \\
\hline Bar ground cover $(\%)$ & $<0.001$ & $<0.001$ & 0.001 & 0.005 & $<0.001$ & $<0.001$ & $<0.001$ \\
\hline Litter cover $(\%)$ & $<0.001$ & $<0.001$ & $<0.001$ & NS & 0.026 & 0.003 & $<0.001$ \\
\hline $\begin{array}{l}\text { Coarse woody debris volume } \\
\text { per transect }\end{array}$ & NS & NS & 0.004 & NS & NS & NS & NS \\
\hline Topsoil \%C & NS & 0.013 & NS & NS & NS & NS & NS \\
\hline Topsoil \%N & 0.022 & 0.030 & 0.044 & NS & NS & NS & NS \\
\hline $\begin{array}{c}\text { Topsoil effective cation exchange } \\
\text { capacity }(\mathrm{cmol}+/ \mathrm{Kg})\end{array}$ & NS & NS & NS & NS & NS & NS & NS \\
\hline Topsoil Bray P (mg/kg) & $<0.001$ & 0.027 & NS & NS & NS & NS & NS \\
\hline
\end{tabular}

\section{References}

1. Shlisky, A.; Alencar, A.A.C.; Nolasco, M.M.; Curran, L.M. Overview: Global fire regime conditions, threats, and opportunities for fire management in the tropics. In Tropical Fire Ecology; Springer: New York, NY, USA, 2009; pp. 65-83.

2. Wright, S.J. The future of tropical forests. Ann. N. Y. Acad. Sci. 2010, 1195, 1-27. [CrossRef] [PubMed]

3. Stork, N.E.; Goosem, S.; Turton, S.M. Status and Threats in the Dynamic Landscapes of Northern Australia's Tropical Rainforest Biodiversity Hotspot: The Wet Tropics. In Biodiversity Hotspots; Springer: London, UK, 2011; pp. 311-332.

4. Le Page, Y.; Morton, D.; Hartin, C.; Bond-Lamberty, B.; Pereira, J.M.C.; Hurtt, G.; Asrar, G. Synergy between land use and climate change increases future fire risk in Amazon forests. Earth Syst. Dyn. 2017, 8, 1237-1246. [CrossRef]

5. Florence, R. Ecology and Silviculture of Eucalypt Forests; CSIRO Publishing: Collingwood, ON, Canada, 1996.

6. Metzger, F.; Schultz, J. Spring Ground Layer Vegetation 50 Years After Harvesting in Northern Hardwood Forests. Am. Midl. Nat. 1981, 105, 44. [CrossRef]

7. Reader, R. Loss of species from deciduous forest understorey immediately following selective tree harvesting. Biol. Conserv. 1987, 42, 231-244. [CrossRef]

8. Fredericksen, T.S.; Ross, B.D.; Hoffman, W.; Morrison, M.L.; Beyea, J.; Johnson, B.N.; Lester, M.B.; Ross, E. Short-term understory plant community responses to timber-harvesting intensity on non-industrial private forestlands in Pennsylvania. Ecol. Manag. 1999, 116, 129-139. [CrossRef]

9. Schumann, M.E.; White, A.S.; Witham, J.W. The effects of harvest-created gaps on plant species diversity, composition, and abundance in a Maine oak-pine forest. Ecol. Manag. 2003, 176, 543-561. [CrossRef]

10. Burke, D.M.; Elliott, K.A.; Holmes, S.B.; Bradley, D. The effects of partial harvest on the understory vegetation of southern Ontario woodlands. Ecol. Manag. 2008, 255, 2204-2212. [CrossRef]

11. ABC 2019. Available online: https:/ / www.abc.net.au/news/2018-12-09/ forestry-survey-rejects-native-forest-logging/10597490 (accessed on 20 February 2019). 
12. Dare, L.; Schirmer, J.; Mylek, M.; Private Native Forest Owner Attitudinal Survey-Northern NSW. Understanding Forest Owners Value and Use of Their Forest Resource. Prepared for the NSW Department of Primary Industries. 2017. Available online: https:/ / www.dpi.nsw.gov.au/forestry/private-native-forestry (accessed on 20 September 2021).

13. Eyre, T.J.; Butler, D.W.; Kelly, A.L.; Wang, J. Effects of forest management on structural features important for biodiversity in mixed-age hardwood forests in Australia's subtropics. Ecol. Manag. 2010, 259, 534-546. [CrossRef]

14. Watson, G.; French, K.; Collins, L. Timber harvest and frequent prescribed burning interact to affect the demography of Eucalypt species. Ecol. Manag. 2020, 475, 118463. [CrossRef]

15. Penman, T.D.; Binns, D.L.; Shiels, R.J.; Allen, R.M.; Kavanagh, R.P. Changes in understorey plant species richness following logging and prescribed burning in shrubby dry sclerophyll forests of south-eastern Australia. Austral Ecol. 2008, 33, 197-210. [CrossRef]

16. Law, B.; Chidel, M.; Britton, A.; Brassil, T. Response of eastern pygmy possums, Cercartetus nanus, to selective logging in New South Wales: Home range, habitat selection and den use. Wildl. Res. 2013, 40, 470-481. [CrossRef]

17. Eyre, T.J.; Ferguson, D.J.; Kennedy, M.; Rowland, J.; Maron, M. Long term thinning and logging in Australian cypress pine forest: Changes in habitat attributes and response of fauna. Biol. Conserv. 2015, 186, 83-96. [CrossRef]

18. Law, B.S.; Chidel, M.; Law, P. Forest bat population dynamics over 14 years at a climate refuge: Effects of timber harvesting and weather extremes. PLoS ONE 2018, 13, e0191471. [CrossRef]

19. Monarrez-Gonzalez, J.C.; Gonzalez-Elizondo, M.S.; Marquez-Linares, M.A.; Gutierrez-Yurrita, P.J.; Perez-Verdin, G. Effect of forest management on tree diversity in temperate ecosystem forests in northern Mexico. PLoS ONE 2020, 15, e0233292. [CrossRef]

20. Putz, F.E.; Zuidema, P.; Synnott, T.; Peña-Claros, M.; Pinard, M.A.; Sheil, D.; Vanclay, J.; Sist, P.; Gourlet-Fleury, S.; Griscom, B.; et al. Sustaining conservation values in selectively logged tropical forests: The attained and the attainable. Conserv. Lett. 2012, 5, 296-303. [CrossRef]

21. Fox, M.D.; Fox, B.J. The effect of fire frequency on the structure and floristic composition of a woodland understorey. Austral Ecol. 1986, 11, 77-85. [CrossRef]

22. Whelan, R.J. The Ecology of Fire; Cambridge University Press: Cambridge, UK, 1995.

23. Peterson, D.W.; Reich, P.B. Prescribed fire in oak savanna: Fire frequency effects on stand structure and dynamics. Ecol. Appl. 2001, 11, 914-927. [CrossRef]

24. Watson, P.; Wardell-Johnson, G. Fire frequency and time-since-fire effects on the open-forest and woodland flora of Girraween National Park, south-east Queensland, Australia. Austral Ecol. 2004, 29, 225-236. [CrossRef]

25. Lewis, T.; Debuse, V.J. Resilience of a eucalypt forest woody understorey to long-term (34-55 years) repeated burning in subtropical Australia. Int. J. Wildland Fire 2012, 21, 980-991. [CrossRef]

26. Russell, M.; Roberts, B. Effects of Four Low-Intensity Burns Over 14 Years on the Floristics of a Blackbutt (Eucalyptus pilularis) Forest in Southern Queensland. Aust. J. Bot. 1996, 44, 315-329. [CrossRef]

27. Russell-Smith, J.; Whitehead, P.J.; Cook, G.D.; Hoare, J.L. Response of Eucalyptus-Dominated Savanna to Frequent Fires: Lessons from Munmarlary, 1973-1996. Ecol. Monogr. 2003, 73, 349-375. [CrossRef]

28. Fairfax, R.; Fensham, R.; Butler, D.; Quinn, K.; Sigley, B.; Holman, J. Effects of multiple fires on tree invasion in montane grasslands. Landsc. Ecol. 2009, 24, 1363-1373. [CrossRef]

29. Lewis, T.; Reif, M.; Prendergast, E.; Tran, C. The effect of long-term repeated burning and fire exclusion on above- and belowground Blackbutt (Eucalyptus pilularis) forest vegetation assemblages. Austral Ecol. 2012, 37, 767-778. [CrossRef]

30. Pellegrini, A.F.A.; Refsland, T.; Averill, C.; Terrer, C.; Staver, A.C.; Brockway, D.G.; Caprio, A.; Clatterbuck, W.; Coetsee, C.; Haywood, J.D.; et al. Decadal changes in fire frequencies shift tree communities and functional traits. Nat. Ecol. Evol. 2021, 5, 504-512. [CrossRef]

31. Reich, P.B.; Peterson, D.W.; Wedin, D.A.; Wrage, K. Fire and vegetation effects on productivity and nitrogen cycling across a forest-grassland continuum. Ecology 2001, 82, 1703-1719. [CrossRef]

32. Burton, J.A.; Hallgren, S.W.; Fuhlendorf, S.D.; Leslie, D.M. Understory response to varying fire frequencies after 20 years of prescribed burning in an upland oak forest. Plant Ecol. 2011, 212, 1513-1525. [CrossRef]

33. Spencer, R.; Baxter, G.S. Effects of fire on the structure and composition of open eucalypt forests. Austral Ecol. 2006, 31, 638-646. [CrossRef]

34. Burgess, E.E.; Moss, P.; Haseler, M.; Maron, M. The influence of a variable fire regime on woodland structure and composition. Int. J. Wildland Fire 2015, 24, 59-69. [CrossRef]

35. Collins, L.; Bradstock, R.; Ximenes, F.; Horsey, B.; Sawyer, R.; Penman, T. Aboveground forest carbon shows different responses to fire frequency in harvested and unharvested forests. Ecol. Appl. 2019, 29, e01815. [CrossRef]

36. Connell, J.H. Diversity in Tropical Rain Forests and Coral Reefs. Science 1978, 199, 1302-1310. [CrossRef]

37. Hughes, T.P. Catastrophes, Phase Shifts, and Large-Scale Degradation of a Caribbean Coral Reef. Science 1994, $265,1547-1551$. [CrossRef] [PubMed]

38. Paine, R.T.; Tegner, M.J.; Johnson, E.A. Compounded Perturbations Yield Ecological Surprises. Ecosystems 1998, 1, 535-545. [CrossRef]

39. Keane, R.E.; Loehman, R.; Clark, J.; Smithwick, E.A.H.; Miller, C. Exploring Interactions among Multiple Disturbance Agents in Forest Landscapes: Simulating Effects of Fire, Beetles, and Disease under Climate Change. In Simulation Modeling of Forest 
Landscape Disturbances; Perera, A.H., Sturtevant, B.R., Buse, L.J., Eds.; Springer International Publishing: Cham, Switzerland, 2015; pp. 201-231.

40. Buma, B.; Wessman, C.A. Disturbance interactions can impact resilience mechanisms of forests. Ecosphere 2011, 2, art64. [CrossRef]

41. Guinto, D.F.; Xu, Z.H.; House, A.P.N.; Saffigna, P.G. Soil chemical properties and forest floor nutrients under repeated prescribedburning in eucalypt forests of south-east Queensland, Australia. N. Z. J. For. Sci. 2001, 31, 170-187.

42. Lemmon, P.E. A spherical densiometer for estimating forest overstory density. For. Sci. 1956, 2, 314-320. [CrossRef]

43. Goodall, D. Some Considerations in the Use of Point Quadrats for the Analysis of Vegetation. Aust. J. Biol. Sci. 1952, 5, 1-41. [CrossRef]

44. Rayment, G.E.; Lyons, D.J. Soil Chemical Methods-Australasia; CSIRO Publishing: Melbourne, Australia, 2010.

45. Ter Braak, C.J.F.; Šmilauer, P. CANOCO Reference Manual and CanoDraw for Windows User's Guide: Software for Canonical Community Ordination (Version 4.5); Biometris, Wageningen University and Research Centre: Wageningen, The Netherlands, 2002.

46. Legendre, P. Spatial Autocorrelation: Trouble or New Paradigm? Ecology 1993, 74, 1659-1673. [CrossRef]

47. Department of Environment and Science. Code of Practice for Native Forest Timber Production on Queensland's State Forest Estate 2020. 2020. Available online: https://parks.des.qld.gov.au/_data/assets/pdf_file/0012/160104/cop-native-foresttimber-production-qpws-estate.pdf (accessed on 20 September 2021).

48. Webb, A.A. Can timber and water resources be sustainably co-developed in south-eastern New South Wales, Australia? Environ. Dev. Sustain. 2012, 14, 233-252. [CrossRef]

49. Harmon, M.E.; Franklin, J.F.; Swanson, F.J.; Sollins, P.; Gregory, S.; Lattin, J.; Anderson, N.H.; Cline, S.P.; Aumen, N.G.; Sedell, J.; et al. Ecology of coarse woody debris in temperate ecosystems. Adv. Ecol. Res. 2004, 34, 59-234. [CrossRef]

50. Grove, S. Tree basal area and dead wood as surrogate indicators of saproxylic insect faunal integrity: A case study from the Australian lowland tropics. Ecol. Indic. 2002, 1, 171-188. [CrossRef]

51. Eyre, T.J. Hollow-bearing trees in large glider habitat in south-east Queensland, Australia: Abundance, spatial distribution and management. Pac. Conserv. Biol. 2005, 11, 23-37. [CrossRef]

52. Butts, S.R.; McComb, W.C. Associations of Forest-Floor Vertebrates with Coarse Woody Debris in Managed Forests of Western Oregon. J. Wildl. Manag. 2000, 64, 95. [CrossRef]

53. Mac Nally, R.; Parkinson, A.; Horrocks, G.; Conole, L.; Tzaros, C. Relationships between terrestrial vertebrate diversity, abundance and availability of coarse woody debris on south-eastern Australian floodplains. Biol. Conserv. 2001, 99, 191-205. [CrossRef]

54. Grove, S.; Meggs, J. Coarse woody debris, biodiversity and management: A review with particular reference to Tasmanian wet eucalypt forests. Aust. For. 2003, 66, 258-272. [CrossRef]

55. Savadogo, P.; Tiveau, D.; Sawadogo, L.; Tigabu, M. Herbaceous species responses to long-term effects of prescribed fire, grazing and selective tree cutting in the savanna-woodlands of West Africa. Perspect. Plant Ecol. Evol. Syst. 2008, 10, 179-195. [CrossRef]

56. Barefoot, C.R.; Willson, K.G.; Hart, J.L.; Schweitzer, C.J.; Dey, D.C. Effects of thinning and prescribed fire frequency on ground flora in mixed Pinus-hardwood stands. Ecol. Manag. 2019, 432, 729-740. [CrossRef]

57. Franklin, C.M.; Nielsen, S.E.; Macdonald, S.E. Understory vascular plant responses to retention harvesting with and without prescribed fire. Can. J. Res. 2019, 49, 1087-1100. [CrossRef]

58. O'Hara, K.; Ramage, B. Silviculture in an uncertain world: Utilizing multi-aged management systems to integrate disturbance. For. Int. J. For. Res. 2013, 86, 401-410. [CrossRef]

59. Jactel, H.; Bauhus, J.; Boberg, J.; Bonal, D.; Castagneyrol, B.; Gardiner, B.; Gonzalez-Olabarria, J.R.; Koricheva, J.; Meurisse, N.; Brockerhoff, E.G. Tree Diversity Drives Forest Stand Resistance to Natural Disturbances. Curr. Rep. 2017, 3, 223-243. [CrossRef]

60. VanDerWoude, C.; De Bruyn, L.A.L.; House, A.P.N. Long-term ant community responses to selective harvesting of timber from Spotted Gum (Corymbia variegata)-dominated forests in south-east Queensland. Ecol. Manag. Restor. 2000, 1, 204-214. [CrossRef]

61. Zhou, D.; Zhao, S.Q.; Liu, S.; Oeding, J. A meta-analysis on the impacts of partial cutting on forest structure and carbon storage. Biogeosciences 2013, 10, 3691-3703. [CrossRef]

62. Deal, R.L. The effects of partial cutting on forest plant communities of western hemlock-Sitka spruce stands in southeast Alaska. Can. J. Res. 2001, 31, 2067-2079. [CrossRef]

63. Kern, C.C.; Palik, B.J.; Strong, T.F. Ground-layer plant community responses to even-age and uneven-age silvicultural treatments in Wisconsin northern hardwood forests. Ecol. Manag. 2006, 230, 162-170. [CrossRef]

64. Bradstock, R.; Keith, D.; Auld, T. Fire and Conservation: Imperatives and Constraints on Managing for Diversity. In Conserving Biodiversity: Threats and Solutions; Bradstock, R.A., Auld, T.D., Keith, D.A., Kingsford, R.T., Lunney, D., Sivertsen, D.P., Eds.; Surrey Beatty \& Sons: Sydney, Australia, 1995; pp. 323-333.

65. Morrison, D.A.; Cary, G.J.; Pengelly, S.M.; Ross, D.G.; Mullins, B.J.; Thomas, C.R.; Anderson, T.S. Effects of fire frequency on plant species composition of sandstone communities in the Sydney region: Inter-fire interval and time-since-fire. Aust. J. Ecol. 1995, 20, 239-247. [CrossRef]

66. Brockway, D.G.; Lewis, C.E. Long-term effects of dormant-season prescribed fire on plant community diversity, structure and productivity in a longleaf pine wiregrass ecosystem. Ecol. Manag. 1997, 96, 167-183. [CrossRef]

67. Williams, P.R.; Congdon, R.A.; Grice, A.C.; Clarke, P.J. Effect of fire regime on plant abundance in a tropical eucalypt savanna of north-eastern Australia. Austral Ecol. 2003, 28, 327-338. [CrossRef] 
68. Pellegrini, A.; Ahlström, A.; Hobbie, S.E.; Reich, P.; Nieradzik, L.P.; Staver, A.C.; Scharenbroch, B.C.; Jumpponen, A.; Anderegg, W.R.L.; Randerson, J.T.; et al. Fire frequency drives decadal changes in soil carbon and nitrogen and ecosystem productivity. Nat. Cell Biol. 2018, 553, 194-198. [CrossRef]

69. Lewis, T. Very frequent burning encourages tree growth in sub-tropical Australian eucalypt forest. Ecol. Manag. 2020, 459, 117842. [CrossRef]

70. Guinto, D.F.; Xu, Z.H.; Saffigna, P.G.; House, A.P.N.; Perera, M.C.S. Soil nitrogen mineralisation and organic matter composition revealed by 13C NMR spectroscopy under repeated prescribed burning in eucalypt forests of south-east Queensland. Soil Res. 1999, 37, 123. [CrossRef]

71. Muqaddas, B.; Zhou, X.; Lewis, T.; Wild, C.; Chen, C. Long-term frequent prescribed fire decreases surface soil carbon and nitrogen pools in a wet sclerophyll forest of Southeast Queensland, Australia. Sci. Total Environ. 2015, 536, 39-47. [CrossRef]

72. Muqaddas, B.; Lewis, T.; Esfandbod, M.; Chen, C. Responses of labile soil organic carbon and nitrogen pools to long-term prescribed burning regimes in a wet sclerophyll forest of southeast Queensland, Australia. Sci. Total Environ. 2019, 647, 110-120. [CrossRef] [PubMed]

73. Butler, O.; Elser, J.J.; Lewis, T.; Mackey, B.; Chen, C. The phosphorus-rich signature of fire in the soil-plant system: A global meta-analysis. Ecol. Lett. 2018, 21, 335-344. [CrossRef] [PubMed] 